\title{
IMPACT OF STUDENT EXCLUSION (INCLUDING SEN STUDENTS) ON THEIR DIGITISATION BEHAVIOUR IN SOCIAL MEDIA
}

\author{
BEATA PROŚCIAK \\ Technical Schools Complex in Leżajsk, \\ ul. Mickiewicza 67, 37-300 Leżajsk \\ Address e-mail: beata@dr-prosciak.pl \\ ORCID ID: https://orcid.org/0000-0003-0717-9931 \\ MARCIN PROŚCIAK \\ University of Silesia, \\ Bankowa 12, 40-007 Katowice \\ Address e-mail: larcelo920@gmail.com \\ ORCID ID: https://orcid.org/0000-0002-8355-4548
}

\begin{abstract}
Aim. The aim of the work is to present the impact of student exclusion (including special educational needs (SEN) students) on their digitisation behaviour in social media. Students with no special educational needs and those with SEN were taken into account. The relationship between SEN exclusion and digital exclusion was indicated. In addition, social exclusion in the family area was included.

Methods. The analysis was based on statistical methods such as range, standard deviation and variance. Surveys were used and were conducted on the Internet through Facebook on national and global scale.

Results. Respondents from around the world feel more excluded by SEN than respondents in Poland. In contrast, respondents with SEN use fewer social networking sites than in groups of gamers, both in Poland and worldwide.

Conclusions. In Poland, SEN is not a barrier for communication with peers in most respondents, unlike in the global respondents. SEN respondents spend less time on social portals because it absorbs their time devoted to studying, which can be an indicator of digital exclusion.

Cognitive value. The aim of the research is to focus on introducing the global and Polish scale of the problem of excluding SEN students from the social media, which was calculated by the author's method based on the indicator of digital exclusion.

Key words: digital exclusion, social exclusion, youth, SEN (special educational needs), networking social, media, social.
\end{abstract}




\section{INTRODUCTION}

Currently, information processing with the use of information and communication technology media is already a cultural, communication, economic and social value (Starowicz, 2013). Reasons for social exclusion of young people can be found in family, school and peer environments. They are also affected by the number of psychological and social stressors (Słupska, 2017). The task of education is to strengthen self-esteem and to protect against exclusion and affect the formation of people resistant to life obstacles (Szczurek-Boruta, 2017). The family plays a very important role in preventing social exclusion. It can be said that it has a psycho-hygienic function as it is about ensuring safety and emotional balance. The family enables the exchange of feelings, shapes the child's world of values and personality, their emotional resistance and maturity (Badowska-Hodyr, 2015). It is worth adding that the vision of the future and present in children's view is terrifying since only about $30 \%$ of children see the current world optimistically (Czykier, 2014).

Contemporary discourse places emphasis on exclusion in various meanings. The exclusion itself is directly related to negative self-marking (Pospiszył, 2015). Social minorities have to endure waves of criticism and contempt for their own group coming from the dominant group. Various factors influence the consolidation of the status of the marginalised group and the most important of them are: social isolation, focus on "here and now," acceptance of a traumatic lifestyle, seeking satisfaction in the conditions in which the individual lives, infantile behaviour, reluctance to compare the current situation with the old life, dreaming unreal dreams, despising one's own group, lack of trust in one's own group, lack of solidarity within one's group, adopting patterns of behaviour characteristic of the dominant group and compliance with the norms of the dominant group. It turns out that minority groups take over the features of the stereotypical loser (Pospiszył, 2015). Social space, which is necessary to stimulate individual initiatives and shape the code of values, is determined by peer contacts. Rejected children attain low social status and usually maintain it at subsequent educational stages. Neglected children are ignored by their peers. The repercussions of exclusion can be reflected in a hostile attitude towards school and education (Pyrzyk-Kuta, 2007).

This paper aims to present the impact of exclusion of students (including SEN students) on their digitisation behaviour in social media. Students with no special educational needs and those with SEN (deep developmental dyslexia, dyslexia, dysgraphia, dysorthography) were taken into account. The relationship between SEN exclusion and digitisation was indicated. In addition, social exclusion in the family and school area was included.

Dorota Ekiert-Grabowska has already conducted research on acceptance among peers at school. At the same time, she distinguished children that were: accepted, moderately accepted, children with balanced status and children isolated and rejected (Pyrzyk-Kuta, 1982). In addition, the Regulation of the Minister of National Education of 30 April 2013 on the rules for the provision and organisation of psycholo- 
gical and pedagogical assistance in public kindergartens, schools and institutions obliged teachers to teach basic diagnostic and therapeutic skills. They are associated with the introduction of alternative work methods, individualised teaching and highlighting the students' strengths. Only the subtle and well-dosed presence of a teacher can create mechanisms protecting the individual's 'I' (Pyrzyk-Kuta, 1982).

Exclusion is often noticed among students with SEN. On the other hand, dyslexia is recognised as a gift, and a dyslexic student's style is defined as a dyslexic cognitive style, characterised by a different way of processing and organising information. Despite the fact that dyslexic cognitive style causes difficulties in learning to write and read, it coexists with other valuable skills that can be described by dyslexic talents. Such skills include:

- spatial imagination and mechanical ability,

- the ability to see connections: analogies, metaphors, paradoxes, similarities, differences, consequences, gaps and disproportions,

- the ability to remember important personal experiences and understand abstract information from the perspective of specific examples,

- the ability to see and use subtle patterns in complex and ever-changing systems of data sets (Eide, \& Eide, 2011).

The term dyslexia itself appeared in medical literature in 1896, when the British ophthalmologist W. Pringle Morgan described a boy who, despite 14 years of continuous efforts, had difficulty writing and reading at a basic level. However, he was considered the smartest student in school (Eide, \& Eide, 2011). Dyslexia is also treated as a synonym for problems, because research on dyslexia focuses on reading, writing and learning difficulties. Therefore, as stated in the most commonly used definition of dyslexia in the United States created by the International Dyslexia Association as the National Institute of Child Health and Development:

Dyslexia is a specific impairment of neurological learning skills. It reveals difficulties in the area of: accurate and/ or fluent language recognition, correct spelling and decoding. These problems result from the phonological processing deficit, which is often surprising in the context of the child's cognitive abilities and appropriate teaching at school. Indirect consequences may include difficulty in understanding the text being read and avoiding reading, which can slow down learning vocabulary and gaining general knowledge (Eide, \& Eide, 2011, pp. 21-22).

This definition "diminishes" the understanding of dyslexia only to difficulties, but it does not extend its meaning to skills and abilities. According to the study, 20\% of US residents can be considered dyslexics (Eide, \& Eide, 2011). In addition, in Europe dyslexia occurs in about $10-15 \%$ of students, and in Poland in $9-10 \%$ (Adamczak, 2011). World literature reports that 10 to $15 \%$ of people have dyslexia (Bentkowski, n.d.).

Other major dysfunctions include ADHD and Asperger Syndrome. Currently, attention deficit hyperactivity disorder (Attention-Deficit/Hyperactivity Disorder - ADHD) is examined by the medical community and recognized not only in children but also in adults (Gaidamowicz et al., 2018). Asperger syndrome is another often recognised condition. It is characterised by symptoms such as 
naivety, lack of firmness, low ability to bond with people, pedantic speech, poor nonverbal communication, clumsiness, impaired coordination of movements and intense concentration on particular objects (Krupa, Lesiczka, \& Telka, 2006).

\section{METHODS}

Statistical methods were used to illustrate the degree of digital exclusion in people with SEN. These methods include range, standard deviation and variance. Moreover, surveys were conducted on the Internet through Facebook on a nationwide and global scale. The popularity factor of social media in the context of digital exclusion was taken into account in relation to two research groups: the students without SEN (including groups of computer gamers, hereinafter referred to as gamers) and the students with SEN in different age ranges. World respondents from twenty Facebook groups and four Polish Facebook groups were examined. The research was conducted in 14 global groups, in which 13 of them have at least 500 members. The exception is one Polish group with less than 500 members, because all existing Polish groups associated with SEN were taken into account, and one group from Africa with about 300 members. In total, three dyslexic groups and one group of gamers were tested in Poland. The international groups on the list include those from the UK, the USA and Africa. In Poland there is a group of parents of children with dyslexia, but the group has formally prevented the possibility of placing a survey on it.

In addition, to calculate the scale of the global exclusion of SEN students from the social media, the author's method was used. It is based on the indicator of digital exclusion, which was be derived from both the surveys conducted among Facebook SEN users in Poland and in the world as well as the estimated population in the world including the numbers of social networking users and weighted average. In addition, the author's weighted sum derived from it was used for comparison of the number of hours spent on social networks in relation to the time devoted to studying. It was be compared between Polish and global groups of people with SEN. In turn, the range allowed to show the difference between Polish and global SEN students not only in the context of digital exclusion but also among family and peers.

Number of all respondents who completed the questionnaires: 474. Including:

- Number of people who completed the survey from Polish groups on dyslexia: 24;

- Number of people who completed the survey from the groups of Polish gamers: 426;

- Number of people who completed the survey from world groups on dyslexia: 21;

- Number of people who completed the survey from groups of world gamers: 3 . 


\section{RESULTS}

The research shows that the majority of more than half of the respondents in groups of gamers, both global and Polish, is over 16 years old or even over 19. Groups of people with SEN around the world are about $30 \%$ of those surveyed who are from 12 up to over 19 years. Only about 10\% of respondents are children with SPE under 11 years old. However, in the surveyed Polish groups with SEN, about $42 \%$ of respondents are under 11 years old, about $40 \%$ are aged $12-15$, about $17 \%$ are over 19 years old and only about $4 \%$ are aged $16-19$.

It turns out that over $30 \%$ of respondents from global groups of computer gamers come from incomplete families. In contrast, the group of Polish gamers has full families in about $86 \%$ of the cases. In turn, respondents from SEN, both in Poland and in the world, have full families in about $90 \%$ of the cases. Figure 1 identifies the caregivers of these individuals:

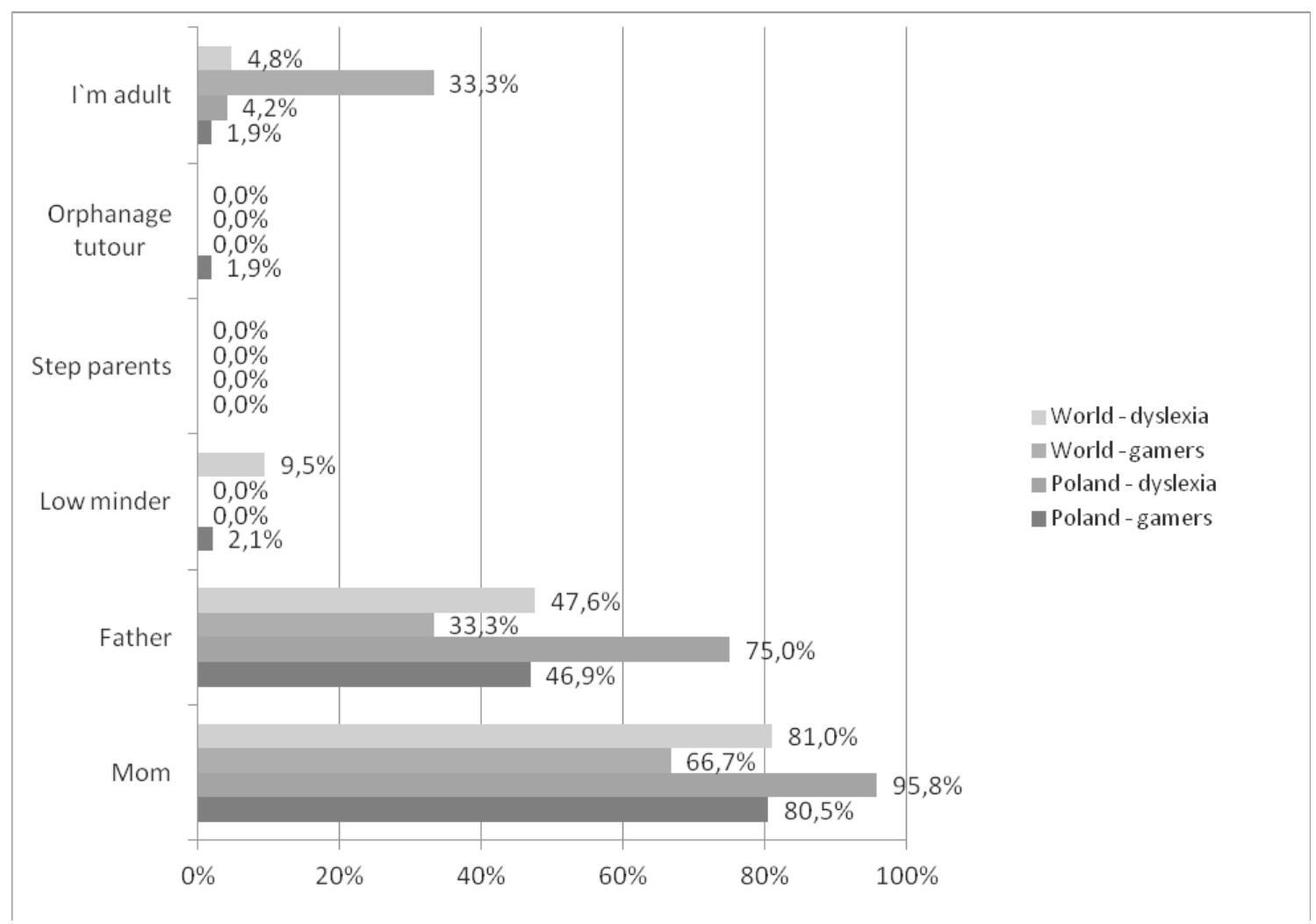

Figure 1. The caregiver

Source: own study

The burden of care in Poland for children with SEN is on the mother in approximately $96 \%$ of the cases and on the fathers in $75 \%$ of the cases. In the world, the differences are greater because children are looked after by around $80 \%$ of mothers and around $48 \%$ of fathers. There is clearly less interest in the problems of children with SEN among the fathers, especially in the global context. A similar trend can be seen among the fathers of gamers in Poland (only about $47 \%$ ) and in the world (only 33\%). In these groups, mostly 
the mothers take care of children (in Polish groups of gamers - about $80 \%$ of mothers does, in the world - about $67 \%$ ).

It is also important is to examine the degree of acceptance and rejection of respondents by those who take care for them, i.e. most often mothers.

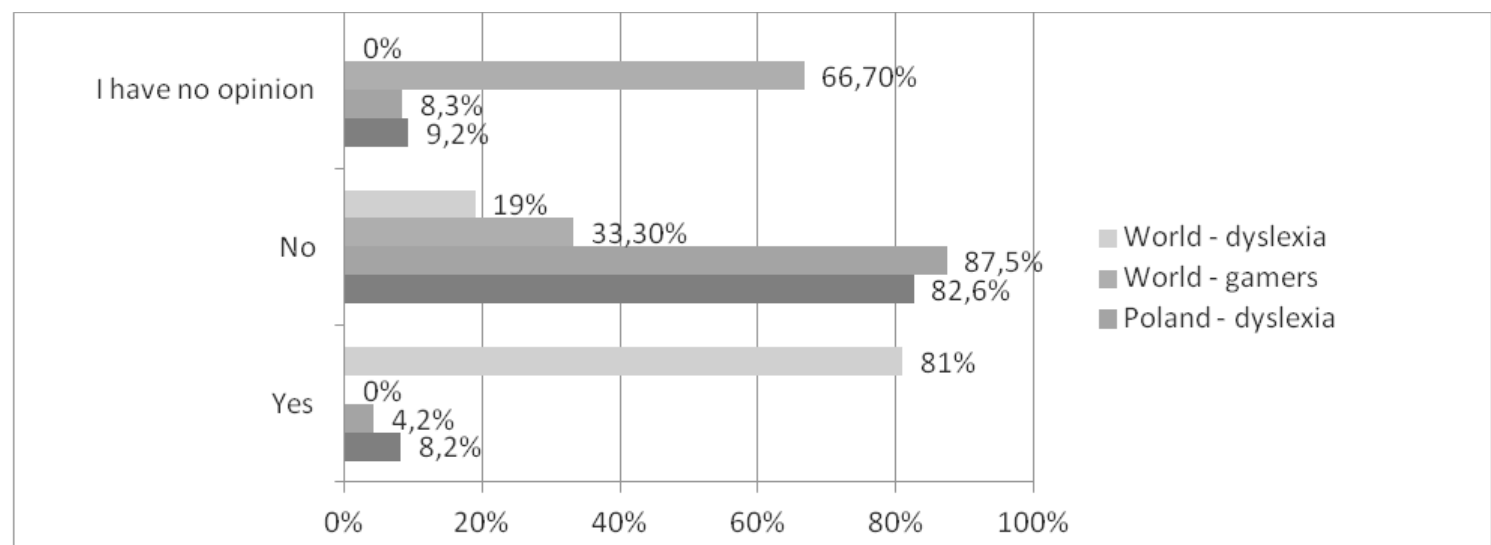

Figure 2. Rejection by the family

Source: own study

Interestingly, only more than $30 \%$ gamers in the world do not feel rejected by the person who brings them up. About $67 \%$ have no opinion on this topic. In contrast, Polish gamers usually feel accepted by their families in approximately $83 \%$ of the cases. Only about $8 \%$ of them experience rejection. However, among Polish groups with SEN, there is a high family acceptance of around $88 \%$. However, a very puzzling and alarming phenomenon has occurred among the respondents with SEN from around the world. $81 \%$ of respondents feel that they are rejected by their parents. Only 19\% are in good relations with the family. Could parents all around the world understand the needs of their children with SEN? In addition, exclusion may apply to peers at school.

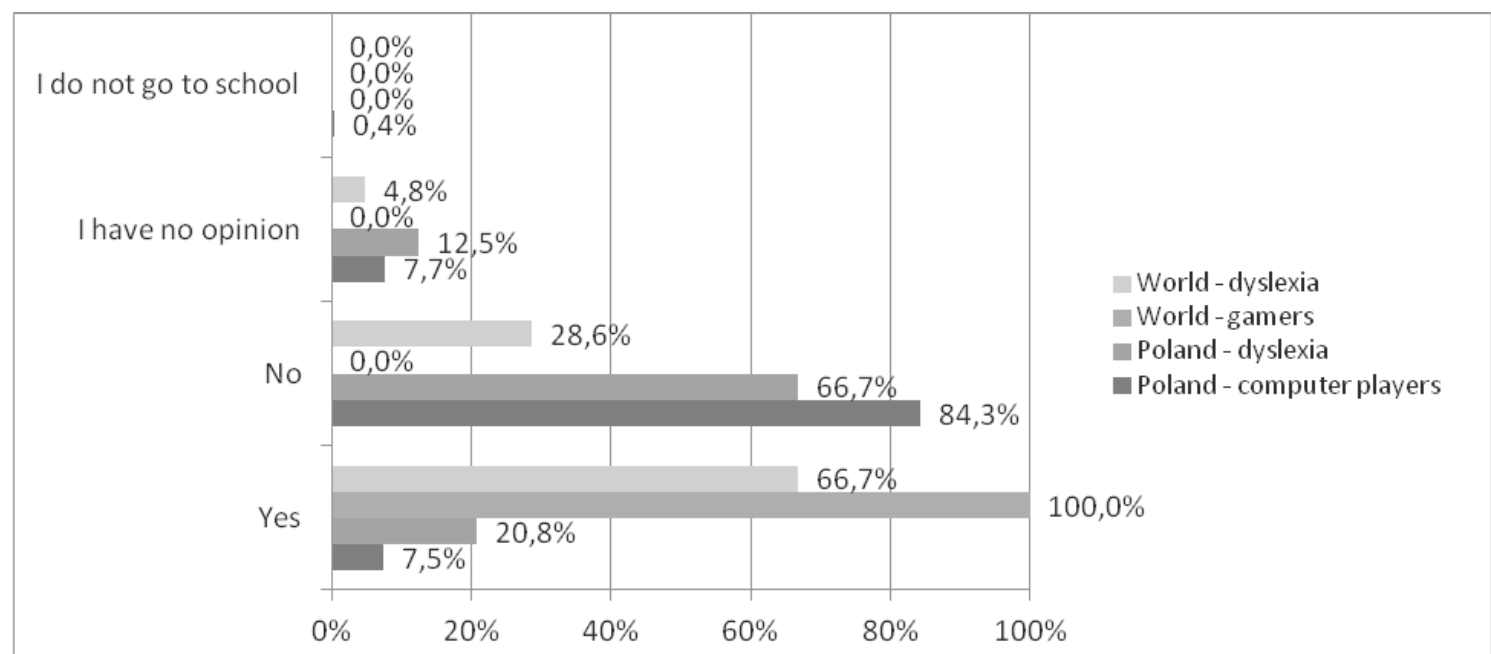

Figure 3. Rejection by peers

Source: own study 
Journal of Education Culture and Society No. 1_2020

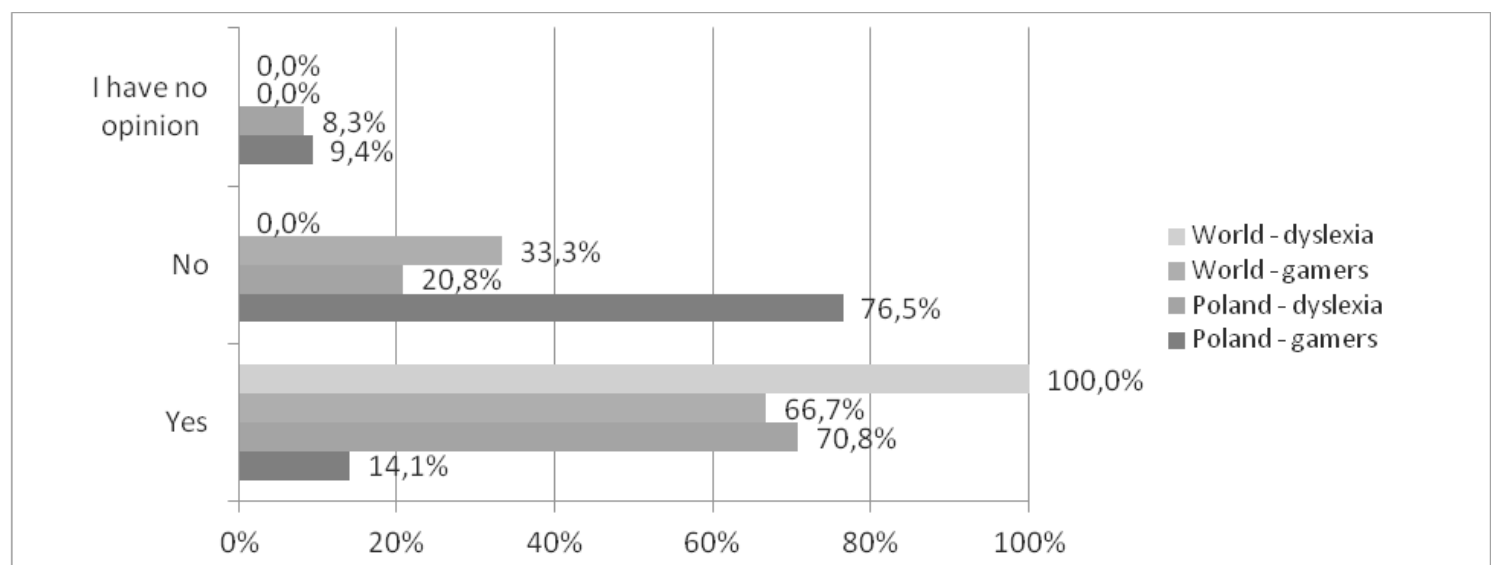

Figure 4. Learning problems

Source: own study

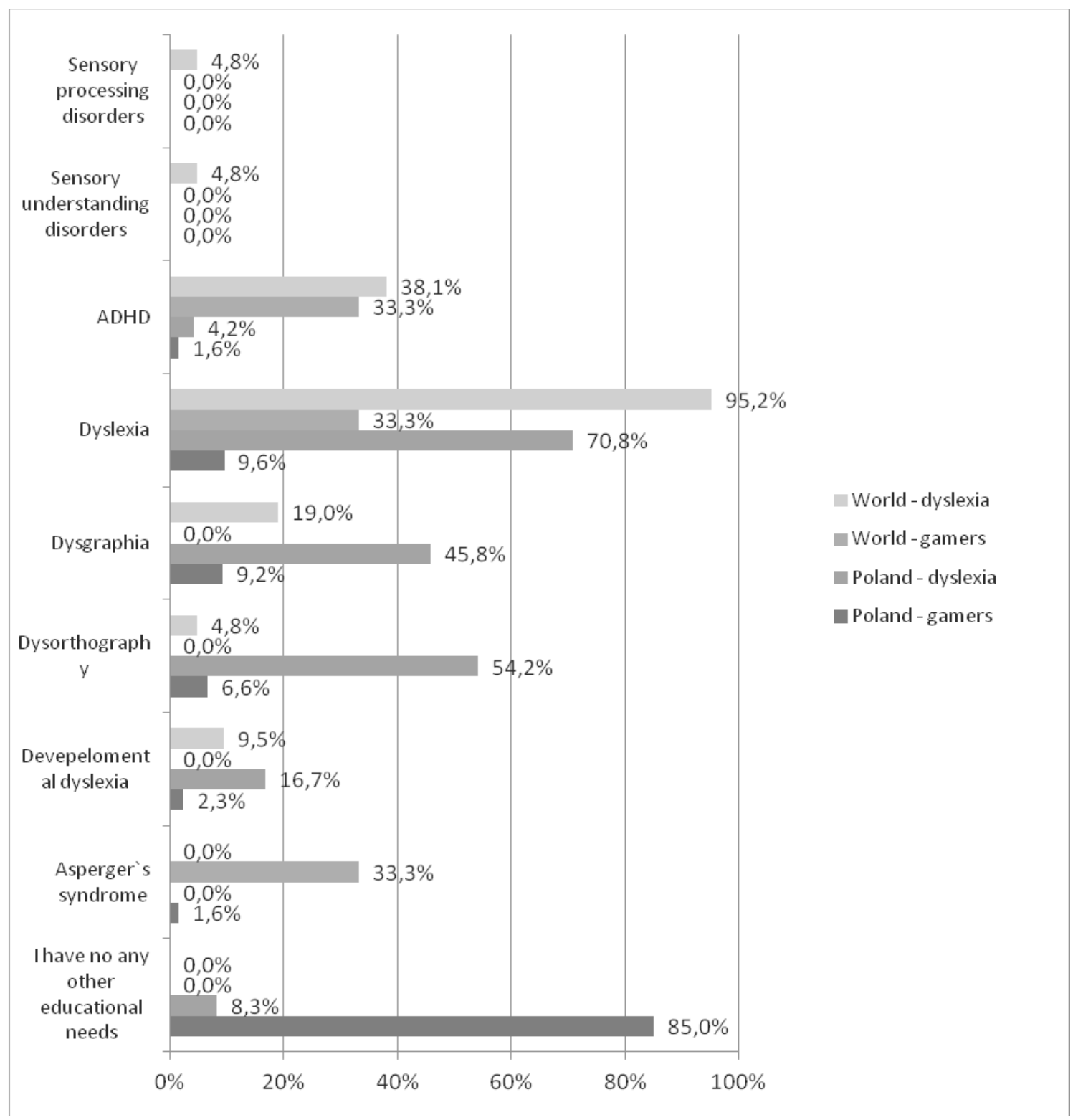

Figure 5. Diagnosed SEN of respondents

Source: own study 
This is another alarming phenomenon on a global scale. It turns out that gamers around the world and the respondents from SEN groups from around the world feel mostly rejected by their peers at school. About $67 \%$ feel excluded by school world in world groups with SEN and 100\% respondents from world groups of gamers. It turns out that the survey was only made by gamers players who admitted to diagnosed SEN.

It turns out that all excluded SEN students from world groups have learning problems. In addition, more than $67 \%$ of gamers in the world admit to having problems at school. The Polish groups of gamers is radically better. For comparison - only about $14 \%$ of respondents from Polish groups of gamers have learning problems. Even among Polish SEN groups, the situation in science is better, because about $70 \%$ of respondents admitted to having some problems with education. It's 30\% less than in the global groups with SEN.

In groups of Polish SEN, about $71 \%$ of respondents admitted to diagnosed dyslexia, about $54 \%$ to dysorthography, about $46 \%$ to dysgraphia and about $17 \%$ to developmental dyslexia. In contrast, the global SEN groups contain mostly dyslexics - about 95\%, dysgraphics - 19\%, dysorthographists - about 5\% and developmental dyslexics - about $10 \%$.

In this context, the notion of time devoted to study turned out to be important.



Figure 6. Number of hours spent on studying per day

Source: own study

The surveyed gamers from around the world (who will also state that they have been diagnosed with SEN) usually spend 2-4 hours a day at home (about $67 \%$ of respondents in this group). About 33\% of this group devote up to 60 minutes a day to study, just like gamers in Poland (about $36 \%$ of them spend 
only 60 minutes a day studying). In addition, around 39\% of Polish gamers admit that they are not studying at all. However, about $17 \%$ of them are enough for 1-2 hours a day to study. In turn, within those $2-4$ hours a day only $7 \%$ of them study. Only about 1\% of the surveyed Polish gamers study over 5 hours.

However, in groups with SEN, both in Poland and worldwide, the situation is slightly different. In Poland, about half of those surveyed with SEN study for 2 to 4 hours a day. In addition, around 33\% of them devote 1 to 2 hours to study. About $12 \%$ of respondents in this group study up to 60 minutes a day, and only about $4 \%$ devote more than 5 hours a day to studying. The same number of respondents do not study at all. In contrast, in global groups with SEN, around $30 \%$ of respondents spend between 2 and 4 hours on studying. About 33\% - from 1 to 2 hours. About 19\% of respondents in this group study up to 60 minutes a day. About $14 \%$ of them do not study at all. It turns out that gamers from Poland usually learn up to 60 minutes a day, or do not study at all. However, about half of the respondents from SEN groups, both in Poland and worldwide, study from 2 to 4 hours a day. The others usually study for between 1 and 2 hours.

It is therefore interesting what social networks young people use and how they use the time outside of their studies.

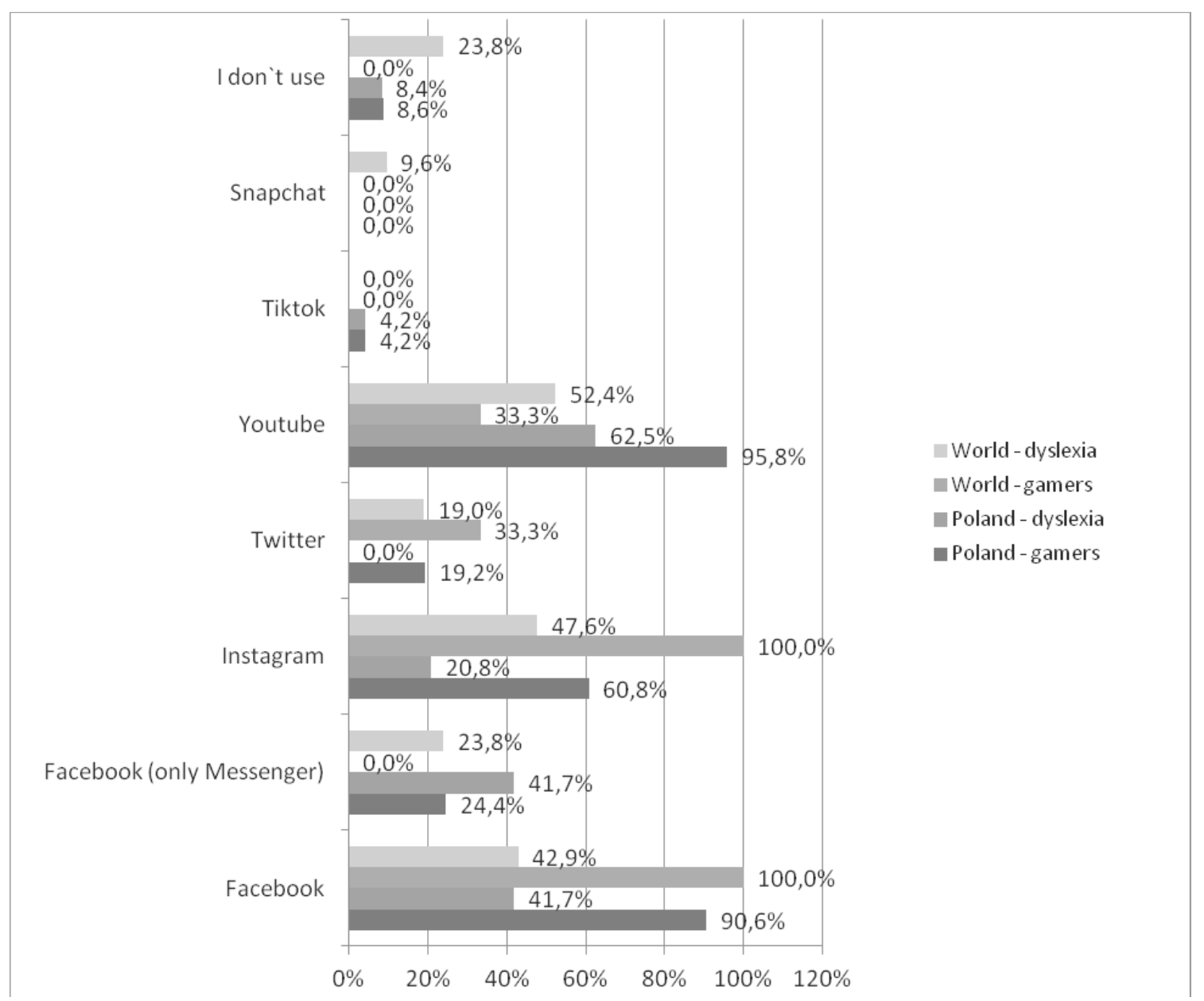

Figure 7. Use of social media

Source: own study 
Research shows that the group of Polish gamers mostly use Youtube (about 96\% of respondents) and Facebook (about 91\%). The world group, however, use almost entirely Instagram and Facebook. In turn, about 33\% of respondents use YouTube and Twitter.

However, around $24 \%$ of respondents from the global SEN groups are excluded from social networking sites and do not use them at all. About $10 \%$ of them use Snapchat. In contrast, in Polish groups with SEN, exclusion is seen only in about $8 \%$ of the respondents. About $50 \%$ of global dyslexic group members use Youtube and Instagram, about $43 \%$ of them use Facebook. It can be clearly seen that around half of the respondents compared in groups of gamers in the country and in the world are digitally excluded.

In Polish groups with SEN, Youtube is the most popular social networking site as about $62 \%$ of respondents use it. Next in line are: Facebook and Messenger used by over $40 \%$ of respondents from these groups and Instagram, which is used by about $21 \%$.

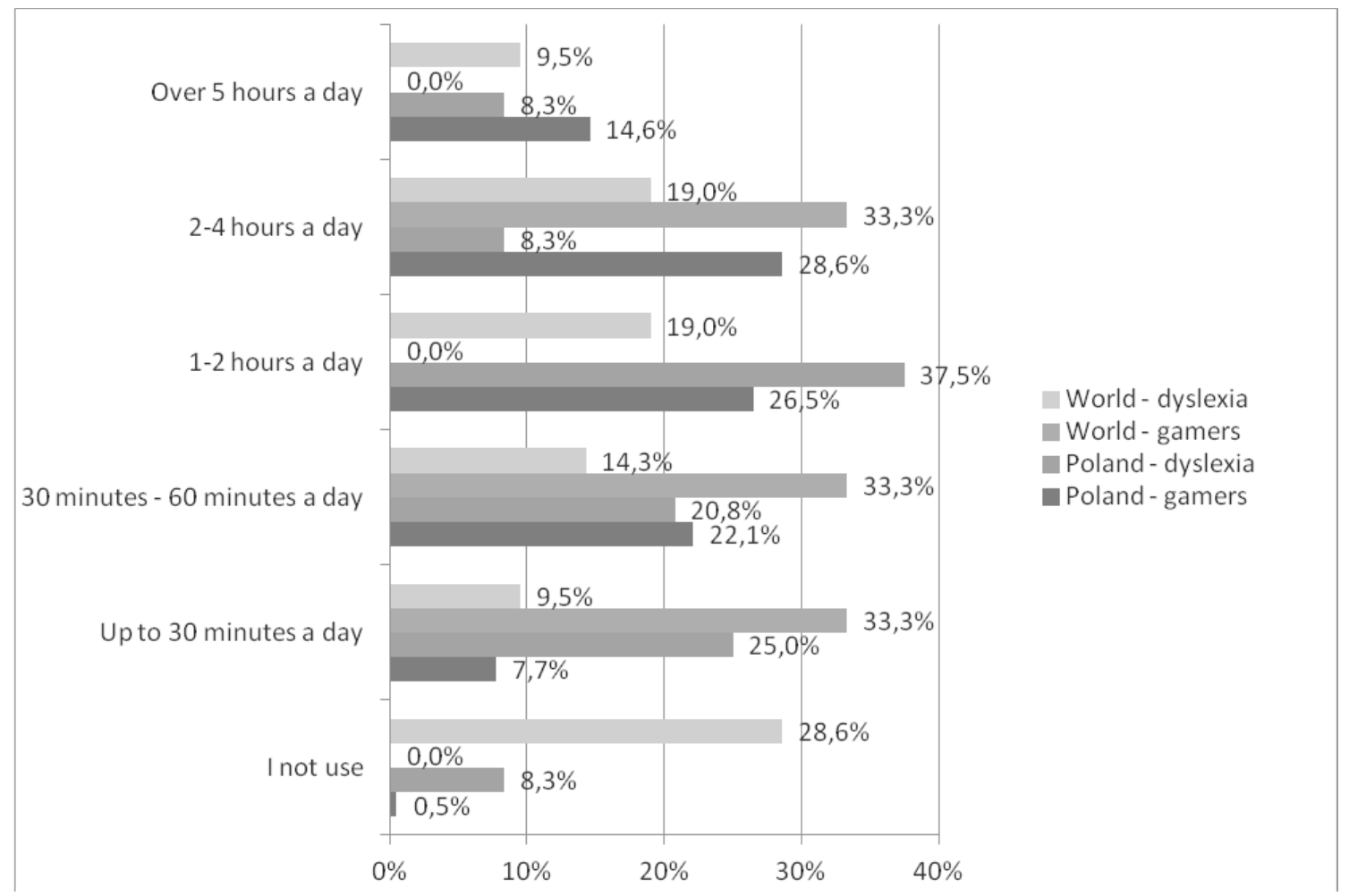

Figure 8. The amount of time spent browsing and using social media Source: own study

About $15 \%$ of Polish gamers spend over 5 hours on social networks. On the other hand, around $30 \%$ of global gamers use social media on average for around 2-4 hours per day.

In addition, it is worth looking at the comparative scales between the number of users of social networking sites and the estimated population of the world. 


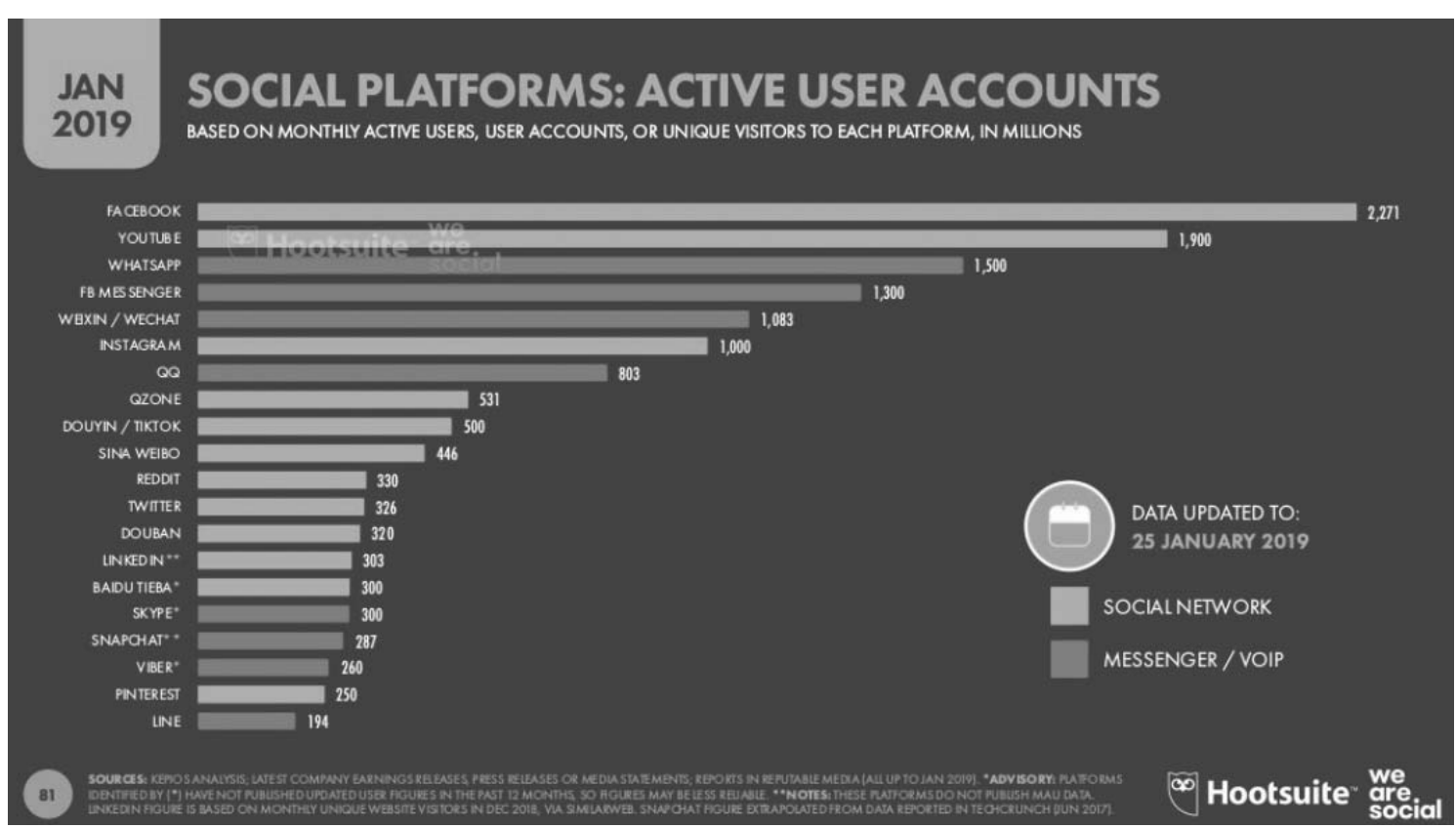

Figure 9. “Digital 2019” report. Total members portals social networks in order from largest to smallest

Source: https:/ / socialpress.pl/2019/02/ilu-uzyzyniknik-yszne-z-sieci-i-social-media-w-2019-roku

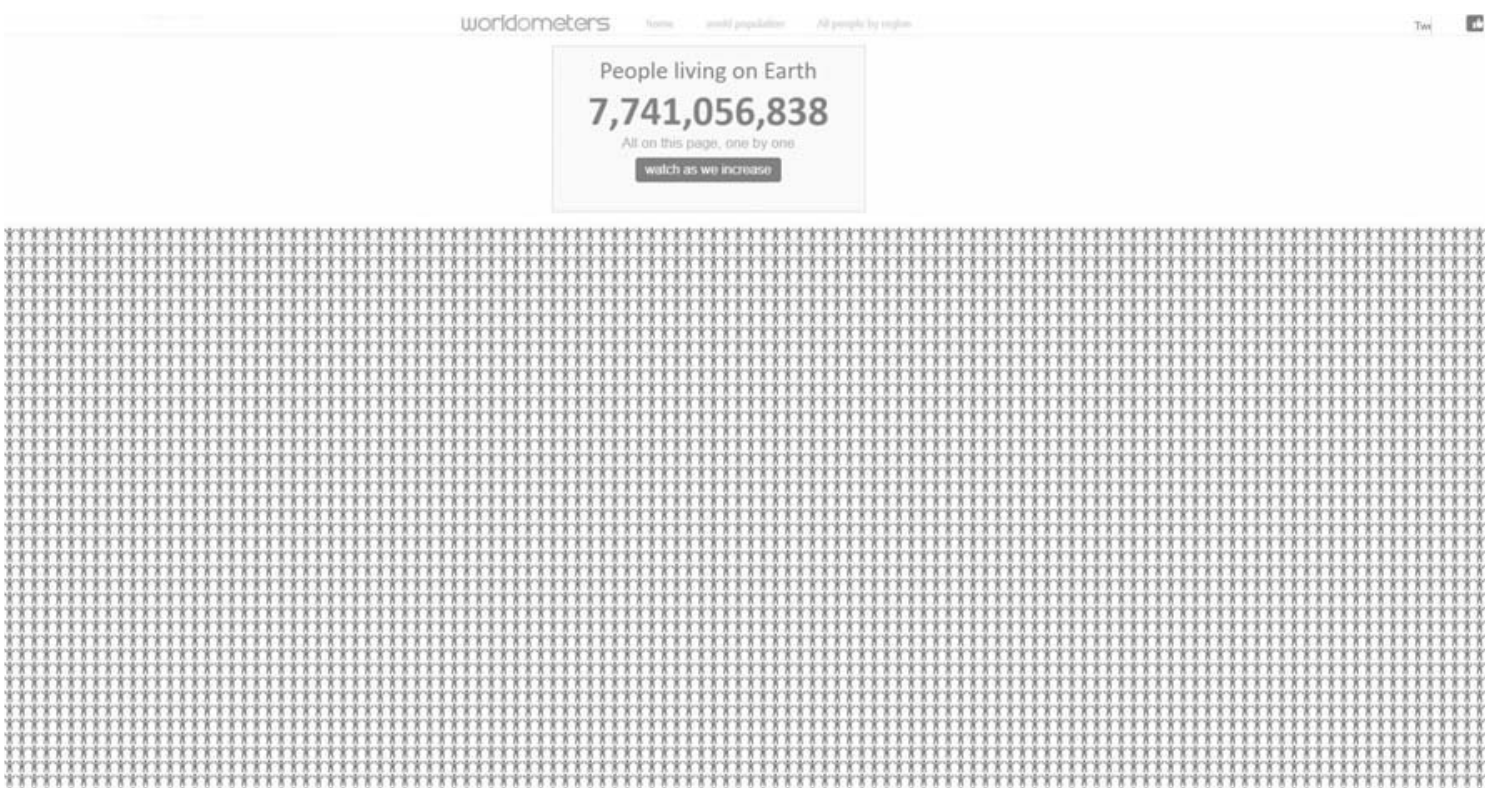

Figure 10. Estimated population in the world including visualization of its number

Source: https://www.worldometers.info/watch/world-population/

Based on this data and survey results, the popularity (using social media) as well as the exclusion (not using social media) coefficient were calculated.

The popularity coefficient (inclusion of a user in social media, involvement in popularity) represents the degree of estimated popularity in social media based on a given data set. Based on this, one can calculate their social exclusion coefficient. 
The author's formula was used, based on the definition of weighted average.

Using the formula:

$S W=\sum_{i=1}^{n} X i * W i$

Where:

$\mathrm{Xi}$ - value of positive data sets

The non-negative coefficient weight of which at least one is different from zero.

In the case of the calculations presented below, the data set will be survey data.

The popularity coefficient was calculated based on the data from the "Digital $2019^{\prime \prime}$ report, which shows the number of users of individual social media in billions. The sum of all media users has set a maximum possible score of 7.584 - the maximum indicator of inclusion in social media. It determines the average number of people a given research group can reach.

Facebook (2.271 billion ) + Youtube (1.9 billion $)+$ Facebook Messenger (1.3 billion) + Instagram ( 1 billion $)+$ Tiktok ( 0.5 billion $)+$ Twitter $(0.326$ billion $)+$ Snapchat $(0.287$ billion $)=7.584$ billion.

It turns out that respondents can reach a maximum of about 7.584 billion users of social networking sites from around the world. Hence, it is worth looking at how many potential recipients reach particular research groups. The basis was the results of surveys from four examined groups.

For this purpose, a weighted sum of the popularity coefficient on social networks for individual survey groups was calculated (based on question 9 "What social networks do you use?") :

WP - popularity coefficient

Wi for the calculation simplicity is given in billions, based on the number of users of specific social media.

The exclusion coefficient is the number of people to whom the user cannot have access through social network sites,

We calculate it in the following way:

$\mathrm{WW}=7.584$ billion (maximal indicator of inclusion in social media) - WP.

For the "Poland - gamers" survey:

$$
\begin{aligned}
W P=(90,6 \% & * 2,271 \text { billion })+(24,4 \% * 1,3 \text { billion })+(60,8 \% * 1 \text { billion }) \\
& +(19,2 \% * 0,326 \text { billion })+(95,8 \% * 1,9 \text { billion })+(4,2 \% * 0,5 \text { billion }) \\
& =(2,0575 \text { billion }+0,3172 \text { billion }+0,608 \text { billion }+0,0625 \text { billion } \\
& +1,8202 \text { mld }+0,021 \text { billion })=4,8864 \cong 4,89 \text { billion }
\end{aligned}
$$

$\mathrm{WW}=7,58$ billion $-4,89$ billion $\cong \cong 2,69$ billion 
On average, gamers in Poland reach 4,89 billion digital recipients around the world and they do not reach an average of 2.69 billion digital worldwide recipients.

For the survey "World - gamers":

$\mathrm{WP}=(100 \% * 2,271 \mathrm{mld})+(100 \% * 1 \mathrm{mld})+(33,3 \% * 0,326 \mathrm{mld})+(33,3 \% *$

$1,9 \mathrm{mld})=100 \% *(2,271 \mathrm{mld}+1 \mathrm{mld}+0,1086 \mathrm{mld}+0,6333 \mathrm{mld})=4,0129 \cong 4,01$

$\mathrm{WP}=(100 \% * 2,271 \mathrm{mld})+(100 \% * 1 \mathrm{mld})+(33,3 \% * 0,326 \mathrm{mld})+(33,3 \% *$

$1,9 \mathrm{mld})=100 \% *(2,271 \mathrm{mld}+1 \mathrm{mld}+0,1086 \mathrm{mld}+0,6333 \mathrm{mld})=4,0129 \cong 4,01$

$$
\begin{aligned}
\text { WP }=(100 \% & * 2,271 \text { billion })+(100 \% * 1 \text { billion })+(33,3 \% * 0,326 \text { billion }) \\
& +(33,3 \% * 1,9 \text { billion }) \\
& =100 \% *(2,271 \text { billion }+1 \text { billion }+0,1086 \text { billion }+0,6333 \text { billion }) \\
& =4,0129 \cong 4,01 \text { billion }
\end{aligned}
$$

WW $=7,58$ billion $-4,89$ billion $\cong 3,57$ billion

While PC gamers in the world have contact with around 4.01 billion users of networking social

networks in the world, they do not have connectivity with 3.57 billion users of social networking sites around the world.

For the "Poland - Dyslexia" survey:

$W P=(41,7 \% * 2,271 \mathrm{mld})+(41,7 \% * 1,3 \mathrm{mld})+(20,8 \% * 1 \mathrm{mld})+(62,5 \% * 1,9 \mathrm{mld})+$ $(4,2 \% * 0,5 \mathrm{mld})=(0,947 \mathrm{mld}+0,5421 \mathrm{mld}+0,208 \mathrm{mld}+1,1875 \mathrm{mld}+0,021 \mathrm{mld})=$ $2,9056 \cong 2,91$ billion

$W P=(41,7 \% * 2,271 \mathrm{mld})+(41,7 \% * 1,3 \mathrm{mld})+(20,8 \% * 1 \mathrm{mld})+(62,5 \% * 1,9 \mathrm{mld})+$ $(4,2 \% * 0,5 \mathrm{mld})=(0,947 \mathrm{mld}+0,5421 \mathrm{mld}+0,208 \mathrm{mld}+1,1875 \mathrm{mld}+0,021 \mathrm{mld})=$ $2,9056 \cong 2,91$ billion

$W P=(41,7 \% * 2,271$ billion $)+(41,7 \% * 1,3$ billion $)+(20,8 \% * 1$ billion $)+$ $(62,5 \% * 1,9$ billion $)+(4,2 \% * 0,5$ billion $)=(0,947$ billion $+0,5421$ billion + $0,208$ billion $+1,1875$ billion $+0,021$ billion $)=2,9056 \cong 2,91$ billion 
WW $=7,58$ billion $-2,91$ billion $\cong \cong 4,67$ billion

On average, gamers in Poland reach 2,91 billion digital recipients around the world, they do not reach 4.67 billion users of social networking sites.

For the survey "World - dyslexia":

$$
\begin{aligned}
W P=(42,9 \% & * 2,271 \text { billion })+(23,8 \% * 1,3 \text { billion })+(47,6 \% * 1 \text { billion }) \\
& +(19 \% * 0,326 \text { billion })+(52,4 \% * 1,9 \text { billion })+(9,6 \% * 0,287 \text { billion }) \\
& =(0,9742 \text { billion }+0,3094 \text { billion }+0,476 \text { billion }+0,0619 \text { billion } \\
& +0,9956 \text { billion }+0,0275 \text { billion })=2,8446 \cong 2,84 \text { billion }
\end{aligned}
$$

$\mathrm{WW}=7,58$ billion $-2,84$ billion $\cong \cong 4,74$ billion

In the world group with SEN, the results are comparable, because SEN respondents reach the 2.84 billion recipients while they do not reach 4.74 billion.

The most excluded from the digital society from social network portals are global groups with SEN. Additionally, this assumption can be confirmed taking into account the fact that among the 20 groups surveyed, which had a total of members, only a few people answered the survey questions. This was commented on in such a way that the respondents around the world do not want to admit to SEN and the self-determination of being a person with SEN already brings them insults and exclusion. In addition, it was the group most socially excluded by both parents and peers.

The opposite phenomenon exists in Polish SEN groups. There is clearly great acceptance for people with SEN among parents as well as peers and school. In this context, it is also worth looking at whether the exclusion by the SEN affects the amount of time spent on studying and on the digital inclusion or exclusion rate.

The weighted sum of time on social networks for individual survey groups (based on question 10, How many hours a day do you spend browsing and using social networks?) :

LG - the value of time spent on using social networking sites

For the "Poland - gamers" survey:

$$
\begin{aligned}
\boldsymbol{L G}=(7,7 \% * & 15 \mathrm{~min})+(22,1 \% * 45 \mathrm{~min})+(26,5 \% * 90 \mathrm{~min})+(28,6 \% * 180 \mathrm{~min}) \\
& +(14,6 \% * 300 \mathrm{~min}) \\
& =(1,155 \mathrm{~min}+9,945 \mathrm{~min}+23,85 \mathrm{~min}+51,48 \mathrm{~min}+43,8 \mathrm{~min}) \\
& =130,23 \mathrm{~min}=2 \text { hours } 10 \text { minutes } 13 \text { secounds } 800 \text { milisecounds }
\end{aligned}
$$


As you can see, gamers from Poland devote on average 2 hours 10 minutes to using social networking sites

For the survey "World - gamers":

$$
\begin{array}{r}
\boldsymbol{L} \boldsymbol{G}=(33,3 \% * 15 \mathrm{~min})+(33,3 \% * 45 \mathrm{~min})+(33,3 \% * 180 \mathrm{~min}) \\
=(5 \mathrm{~min}+15 \mathrm{~min}+60 \mathrm{~min})=\mathbf{1} \text { hour } 20 \text { minutes }
\end{array}
$$

In turn, gamers from the world definitely devote less time, about 1 hour 20 minutes. The same is true for respondents from Polish SEN groups.

For the survey "Polish - dyslexia":

$$
\begin{aligned}
\boldsymbol{L} \boldsymbol{G}=(25 \% * & 15 \mathrm{~min})+(20,8 \% * 45 \mathrm{~min})+(37,5 \% * 90 \mathrm{~min})+(8,3 \% * 180 \mathrm{~min}) \\
& +(8,3 \% * 300 \mathrm{~min}) \\
& =(3,75 \mathrm{~min}+9,36 \mathrm{~min}+33,75 \mathrm{~min}+14,94 \mathrm{~min}+24,9 \mathrm{~min})=130,23 \mathrm{~min} \\
& =86,7 \mathrm{~min}=\mathbf{1} \text { hour } 26 \text { minutes } 42 \text { secounds }
\end{aligned}
$$

Respondents from Polish SEN groups spend about 1 hour and 2 minutes daily browsing social networking sites.

For the survey "World - dyslexia":

$$
\begin{aligned}
\boldsymbol{L} \boldsymbol{G}=(9,5 \% & * 15 \mathrm{~min})+(14,3 \% * 45 \mathrm{~min})+(19 \% * 90 \mathrm{~min})+(19 \% * 180 \mathrm{~min})+(9,5 \% \\
& * 300 \mathrm{~min})=(1,425 \mathrm{~min}+6,435 \mathrm{~min}+17,1 \mathrm{~min}+34,2 \mathrm{~min}+28,5 \mathrm{~min}) \\
& =\mathbf{8 7}, \mathbf{6 6} \mathbf{m i n}=\mathbf{1} \text { hour } \mathbf{2 7} \text { minutes } 20 \text { secounds }
\end{aligned}
$$

SEN respondents spend a little more time in the digital world. It is about 1 hour 27 minutes a day.

It turns out that the most of the time (over two hours) is spent by Polish gamers on browsing social networking sites. In contrast, the remaining research groups spend over an hour a day. In this context, it is worth looking at how many hours the subjects spend on studying.

Here is the weighted number of hours devoted to the teachings for each group questionnaire (based on 8 questions "How many hours a day do you spend studying?") :

LGN - Number of hours studying

For the "Poland - gamers" survey: 


$$
\begin{aligned}
& \boldsymbol{L} \boldsymbol{G N}=(35,9 \% * 30 \mathrm{~min})+(16,9 \% * 90 \mathrm{~min})+(7 \% * 180 \mathrm{~min})+(1,2 \% * 300 \mathrm{~min}) \\
& =10,77 \mathrm{~min}+15,21 \mathrm{~min}+12,6 \mathrm{~min}+3,6 \mathrm{~min}=42,18 \mathrm{~min} \\
& =42 \text { minutes } 10 \text { secounds } 800 \text { milisecounds }
\end{aligned}
$$

Polish gamers spend only about 42 minutes on studying. The situation looks a little better for gamers from around the world.

For the survey "World - gamers":

$L G N=(33,3 \% * 30 \mathrm{~min})+(66,7 \% * 180 \mathrm{~min})=10 \mathrm{~min}+60 \mathrm{~min}=1$ hour 10 minutes

Gamers from around the world devote 1 hour and 10 minutes to study.

For the "Poland - Dyslexia" survey:

$$
\begin{gathered}
\boldsymbol{L G N}=(12,5 \% * 30 \mathrm{~min})+(33,3 \% * 90 \mathrm{~min})+(45,8 \% * 180 \mathrm{~min})+(4,2 \% * 300 \mathrm{~min}) \\
=3,75 \mathrm{~min}+30 \mathrm{~min}+33,75 \mathrm{~min}+82,44 \mathrm{~min}+12,6 \mathrm{~min}=162,54 \mathrm{~min} \\
=\mathbf{2} \text { hours } 42 \text { minutes } 32 \text { secounds } \mathbf{4 0 0} \text { milisecounds }
\end{gathered}
$$

Polish SEN groups need to study a lot more, about 2 hours 42 minutes.

For the survey "World - dyslexia":

$$
\begin{aligned}
\boldsymbol{L} \boldsymbol{G N}=(19 \% & * 30 \mathrm{~min})+(33,3 \% * 90 \mathrm{~min})+(29 \% * 180 \mathrm{~min})+(14,3 \% * 300 \mathrm{~min}) \\
& =5,7 \mathrm{~min}+60 \mathrm{~min}+52,2 \mathrm{~min}+42,9 \mathrm{~min}=87,66 \mathrm{~min} \\
& =2 \text { hours } 40 \text { minutes } 48 \text { seconds }
\end{aligned}
$$

It is similar in SEN groups around the world. They need to study more than 2 hours 40 minutes a day.

It turns out that the most of the time (over two hours) is spent by Polish gamers on browsing social networking sites. In addition, to illustrate the degree of social exclusion in the family or at school, methods such as range, standard deviation and variance can be used.

The range represents how large the data range is. It can be calculated by taking the values from the largest to the smallest.

$$
\mathbf{R}=\mathbf{x}_{\text {max }}-\mathbf{x}_{\text {min }}
$$

Standard deviation is denoted by the symbol $\sum$ (read: sigma). The value of standard deviation shows how varied the statistical data is. The higher the deviation value, the more dispersed this data is. Standard deviation is calculated from the following formula: The variance is a standard deviation of reality raised to the square of (the value is equal to the value, we obtain the root in the formula for the deviation standard): 


$$
\sigma=\sqrt{\frac{\left(x_{1}-\bar{x}\right)^{2}+\left(x_{2}-\bar{x}\right)^{2}+\ldots+\left(x_{n}-\bar{x}\right)^{2}}{n}}
$$

It is worth looking at least question 4. Range for question 4 ("Do you feel rejected in the family or by the person who looks after you?" $)$ :

$\mathrm{R}$ (I have no opinion $)=9.2 \%-0=\mathbf{9 . 2} \%$

$\mathrm{R}(\mathrm{No})=82.6 \%-19 \%=63.6 \%$

$\mathrm{R}($ Yes $)=81 \%-0 \%=\mathbf{8 1} \%$

The difference between the smallest and largest value in the surveys is $81 \%$. The response interval between subjects with and without SEN is very large.

Range for question 5 ("Do you feel rejected (excluded) by peers at school?"):

$\mathrm{R}(\mathrm{I}$ do not go to school $)=0.4 \%-0 \%=\mathbf{0 . 4} \%$

$\mathrm{R}$ (I have no opinion) $=12.5 \%-0 \%=\mathbf{1 2 . 5} \%$

$\mathrm{R}(\mathrm{No})=84.3 \%-0 \%=84.3 \%$

$\mathrm{R}($ Yes $)=100 \%-7.5 \%=\mathbf{9 2 . 5} \%$ 92.5\%.

An even greater range of answers occurs in question 5 and amounts to

Range comparing questions 4 and 5:

$\mathrm{R}(\mathrm{No})=84.3 \%-63.6 \%=21.7 \%$

$\mathrm{R}($ Yes $)=100 \%-81 \%=\mathbf{1 9} \%$

The range of peer and guardian exclusion responses is definitely smaller, as it is $19 \%$.

It is also worth looking at the standard deviation for question 5 regarding peer exclusion at school.

Arithmetic mean for the input of question 5 ("Do you feel rejected (excluded) by peers at school?") (For the answer "Yes"):

$$
\overline{\boldsymbol{x}} \overline{\boldsymbol{x}}=\frac{100 \%+66,7 \%+20,8 \%+7,5 \% 100 \%+66,7 \%+20,8 \%+7,5 \%}{4}=\frac{195 \% 195 \%}{4}=48,75 \%
$$

Standard deviation is calculated as follows:

$$
\sigma=\sqrt{\frac{(100-48,75)^{2}+(66,7-48,75)^{2}+(20,8-48,75)^{2}+(7,5-48,75)^{2}}{4}}
$$

$$
\sqrt{\frac{(100-48,75)^{2}+(66,7-48,75)^{2}+(20,8-48,75)^{2}+(7,5-48,75)^{2}}{4}}
$$

$$
\sigma=\sqrt{\frac{(51,25)^{2}+(17,95)^{2}+(-27,95)^{2}+(-41,25)^{2}}{4}}
$$


$\sqrt{\frac{(51,25)^{2}+(17,95)^{2}+(-27,95)^{2}+(-41,25)^{2}}{4}}$

$\sigma=\sqrt{\frac{2626,5625+322,2025+781,2025+1701,5625}{4}}$

$\sqrt{\frac{2626,5625+322,2025+781,2025+1701,5625}{4}}=\sqrt{\frac{5431,53}{4}} \sqrt{\frac{5431,53}{4}}=$

$\sqrt{1357,8825} \cong \sqrt{1357,8825} \cong 36,84$

It can be said that the average deviation of the result from the average, i.e. exclusion by peers at school, is different in Poland and in the world. This difference can be seen especially among those with and without SEN.

The value under the root in the calculation of standard deviation is equal to the variance: $\sigma^{2}=1357,8825$.

It can be seen that the results are very scattered, especially when it comes to the world and Poland. The dispersion of results is very large when it comes to the situation of respondents with SEN in Poland and in the world. One can see the scale of the rejection problem. In Poland, respondents with SEN usually do not feel rejected by peers and guardians, unlike those with SEN worldwide.

\section{DISCUSSION}

The respondents from around the world feel more excluded because of SEN than the respondents in Poland. In contrast, SEN respondents use fewer social networking sites than in groups of gamers, both in Poland and worldwide. Among the respondents, both in the country and in the world, only about $10 \%$ of respondents come from incomplete or broken families. Most of the respondents in groups with SEN and gamers do not feel rejected by their family. However, when they are excluded by peers, one can see a huge difference in national and global research. In Polish groups of gamers, over $80 \%$ of respondents do not feel rejected, and among Polish SEN groups over $60 \%$ of respondents. However, in global groups with SEN only about 30\% of respondents do not feel rejected. In addition, in the surveyed Polish SEN groups it was revealed that they have learning problems in about $70 \%$. While the world SEN respondents have identified themselves in 100\% they have problems in science. In turn, among Polish respondents from the group of gamers about $80 \%$ admitted that they have no problems with studying. Interestingly, among the respondents from the global groups of gamers, only individual respondents did the survey, including all of the SEN group who admitted that they 
have learning problems.

In Poland, SEN are not a barrier in communication with peers for most respondents, unlike global respondents. The studied groups of gamers in the world are usually closed communities that are not interested in the problems of SEN and digital exclusion. Polish gamers most often use social media. SEN respondents spend less time on social portals because it absorbs their time devoted to studying, which can be an indicator of digital exclusion.

Among the digitisation behaviours, the first conclusion is that the exclusion because of SEN affects the digital exclusion of respondents and the reluctance to talk about their problems on social networking sites around the world. The opposite phenomenon can be observed among the users of Polish social networking sites who do not hide their exclusion because of SEN and for the most part do not feel excluded because of it in the family and at school.

In addition it its worth emphasizing that the originality of the research approach lies in giving the scale of the global problem of excluding SEN students from the social media which was calculated by the author's method. It is an indicator based on digital exclusion coefficient which was derived both from research among Facebook SEN users in Poland and in the world as well as the estimated population in the world including the number of social network users and weighted average. In addition, the author's weighted sum derived from it was used for comparison of the number of hours spent on social networks in relation to time devoted to studying. Polish and global SEN groups were compared. What is more, the range allowed to show the difference between Polish and global SEN groups even more accurately in the context of not only digital exclusion but in family and peer exclusion as well.

\section{REFERENCES}

[1] Adamczak, N. (2011). Ocena wybranych parametrów układu wzrokowego u dzieci i młodzieży $z$ miasta Poznania ze zdiagnozowana dysleksja [Assessment of selected parameters of the visual system in children and adolescents from the city of Poznan with diagnosed dyslexia], doctoral dissertation. Poznań: Katedra Optometrii i Biologii Układu Wzrokowego Uniwersytet Medyczny im. Karola Marcinkowskiego w Poznaniu.

[2] Badowska-Hodyr, M. (2015). Postawy rodzicielskie i funkcjonowanie dziecka z perspektywy uwięzionych rodziców w świetle teorii przywiązania Johna Bowlbyego [Attitudes and functioning of parental child from the perspective of imprisoned parents in light of attachment theory of John Bowlby]. [In:] D. Kowalczyk (Ed.), Resocjalizacja penitencjalna w kontekstach interdyscyplinarnych [Rehabilitation penitentiary in interdisciplinary contexts]. Wrocław: Oficyna Wydawnicza Atut - Wrocławskie Wydawnictwo Oświatowe.

[3] Bentkowski, P. (n.d). Dysleksja - charakterystyka zjawiska [Dyslexia - characteristics of the phenomenon]. Retrieved from: http://www.psychologia.edu.pl/czytelnia/50-artykuly/699dysleksja-8211-charakterystyka-zjawiska.html

[4] Eide, B. L., \& Eide, F. F. (2011). Dyslektyczne talenty. Jak wydobyć ukryty potencjał dyslektycznego mózgu [Dyslexic Talents. How to bring out the hidden potential of dyslexic brain]. Gdańsk: Harmonia Universalis.

[5] Czykier, K. (2014). Audiowizualne doświadczanie świata. Kontekst międzypokoleniowy [Audiovisual experience of the world. Intergenerational context]. Warszawa: Wydawnictwo Akademickie Żak. 
[6] Krupa, B., Lesiczka, K., \& Telka, W. (2016). Dziecko z zespołem Aspergera (ASD) - problemy imożliwości wsparcia [Child syndrome Asperger (ASD) - problems and possibilities of support]. Retrieved from:https://depot.ceon.pl/bitstream/handle/123456789/9938/ Asperger\%20-\%20artyku\%C5\%82.pdf?sequence=1\&isAllowed=y

[7] Pospiszył, I. (2015). Syndrom frajera, czyli uniwersalność strategii obronnych grup dyskryminowanych [Syndrome gull, i.e. the universality of defensive strategies discriminated groups] (pp. 157-164). [In:] D Kowalczyk, A. Szecówka, P. Kwiatkowski (Eds.), Tradycje i perspektywy optymalizowania profilaktyki społecznej oraz resocjalizacji [The traditions and perspectives of optimizing social prevention and rehabilitation]. Wrocław: Oficyna Wydawnicza "Atut" - Wrocławskie Wydawnictwo Oświatowe.

[8] Pyrzyk-Kuta, A. (2007). Niechciany, pomijany, samotny - wykluczenie rówieśnicze jako obszar pedagogicznej nieuwagi i niewrażliwości [Unwanted, overlooked, lonely - peer exclusion as an area of pedagogical inattention and insensitivity] (pp. 91-102). [In:] A. SzczurekBoruta, K. Jas, A Marszałek (Eds.), Człowiek wykluczony i człowiek w sytuacji zagrożenia wykluczeniem społecznym, edukacyjnym, kulturowym - wyzwania, powinności, pedagogiki, zadania [An excluded man and a person in the situation of threat of social, educational, cultural exclusion - challenges, duties, pedagogy, tasks]. Torun: Wydawnictwo Adam Marszałek.

[9] Słupska, K. (2017). Młodzi rozczarowani. O niespełnionych marzeniach, troskach i bolączkach współczesnego młodego pokolenia (wybrane konteksty) [Young disappointed. About unfulfilled dreams, worries and ills of the modern young generation (selected contexts)]. [In:] J. Spętana, D. Krzysztofiak, E. Włodarczyk (Eds.), Od wykluczenia do wsparcia. W przestrzeni wspótczesnych problemów społecznych [From exclusion to support. In the space of contemporary social problems] (pp. 77-90). Kraków: Oficyna Wydawnicza „Impuls”.

[10] Starowicz, R. L. (2013). Wtaczenie cyfrowe - droga do reintegracji spotecznej [Digital inclusion - the path to social reintegration]. Warszawa: Wydawnictwo Uniwersytetu Warszawskiego.

[11] Szczurek-Boruta, A. (2017). Człowiek wykluczony i człowiek w sytuacji zagrożenia wykluczeniem społecznym, edukacyjnym, kulturowym - wyzwania, powinności pedagogiki, zadania [An excluded man and a man in a situation of danger of social, educational and cultural exclusion - challenges, duties of pedagogy, tasks]. Torun:Wydawnictwo Adam Marszałek.

[12] Gaidamowicz, R., Deksnytè, A., Palinauskaitė, K., Aranauskas, R., Kasiulevičius, V., Šapoka, V., \& Aranauskas, L. (2018). ADHD - plaga XXI wieku? [ADHD - the scourge of the 21st century]. Psychiatria Polska 52(2), 287-307. DOI: https:// doi.org/10.12740/PP/67111 


\section{APPENDIX:}

Below is a list of groups that have completed surveys in Poland and in the world together with the number of members in each group. The list includes groups that completed surveys and those who rejected and did not post them.

As of November 1, 2019:

Polish groups related to dyslexia:

Dyslexia (285 members)

Link: https://www.facebook.com/murakowska/

Dyslexia - support and development (1,928 members)

Link: https://www.facebook.com/groups/404859333223219/

Dyslexia and foreign languages (907 members)

Link: https://www.facebook.com/groups/1776049222702182/

Surveys did not include the group:

Parents with dyslexia (354 members)

Link: https://www.facebook.com/RodziceZDysleksja/

Polish groups related to playing computer games:

ArQuelownia (103,429 members)

Link: https://www.facebook.com/groups/ArQuelownia/

World groups associated with dyslexia:

Dyslexia (33,852 members)

Link: https://www.facebook.com/DyslexiaWorld/

Dyslexia (19,108 members)

Link: https:/ / www.facebook.com/groups/5967552556/

Teacher's help for Dyslexia (831 members)

Link: https://www.facebook.com/groups/157741448430053/

Dyslexia Group. Increase awareness and understanding. (12,145 members)

Link: https://www.facebook.com/groups/bowde/

Dyslexia - UK, Support \& Advice . (2,120 members)

Link: https:/ / www.facebook.com/groups/1573360089624568/

Dyslexia and Learning Disability Support Group (2,764 members)

Link: https://www.facebook.com/groups/596952743826684/

Dyslexia, Dyscalculia and LD Parent Support Group (6,891 members)

Link: https://www.facebook.com/groups/161135210754731/

Dyslexia Parent Support Group Indonesia (4,664 members)

Link: https://www.facebook.com/BicaraDisleksia/

Stealth Dyslexia Support (717 members)

Link: https://www.facebook.com/groups/StealthDyslexia/

Dyslexia Diagnosticians - Texas (1,188 members)

Link: https://www.facebook.com/groups/499138114182867/

Dyslexia Help Africa (321 members)

Link: https://www.facebook.com/groups/1430904680300392/ 
Surveys did not include the group:

Dyslexia Support Australia (14,580 members)

Link: https:// www.facebook.com/groups/DyslexiaSupportAustralia/

PowerDys - The Power of Dyslexia community (522 members)

Link: https://www.facebook.com/groups/PowerDys/

World groups related to playing computer games:

Gaming Geeks (335,363 members)

Link: https://www.facebook.com/GGeex/

Gaming HQ Community (7,795 members)

Link: https://www.facebook.com/groups/FollowGamingHQ/

FAMOUS (FAL) (1,610,004 members)

Link: https://www.facebook.com/groups/987766954595390/

Surveys did not include the group:

Frontal Gaming (31,776 members)

Link: https://www.facebook.com/groups/329763001068325/

Retro Gaming 101 - The Group (43,292 members)

Link: https://www.facebook.com/groups/107240076623619/

GAMER FORUM INDONESIA (FGI) (37,057 members)

Link: https://www.facebook.com/groups/ForumGamerID/

Realers 4G likers (we make you famous) (16,008 members)

Link: https://www.facebook.com/groups/2466853650022337/ 